\title{
Initial Toxicity Screening Techniques of Skin Contact Materials Using Glutathione
}

\author{
HyeSeon $\mathrm{Heo}^{1}$, Minji $\mathrm{An}^{1}$, Mi-Sook Yoon ${ }^{2}$, Yeong-Chul Park ${ }^{1 *}$ \\ ${ }^{1}$ Department of Toxicity Assessment \& GLP Center, Daegu Catholic University, Gyeongsan-si, Gyeongsangbuk-do, Korea \\ ${ }^{2}$ Department of Beauty Coordination, Keimyung College University, Daegu, Korea
}

\author{
"Corresponding author: Yeong-Chul Park, \\ Department of Toxicity assessment \& \\ GLP center, Deagu Catholic University, \\ Gyeongsan-si, Gyeongsangbuk-do 38430 , \\ Korea \\ Tel.: +82538503635 \\ Fax: +82533597489 \\ Email: ycpark@cu.ac.kr
}

Received January 3, 2019

Revised February 11, 2019

Accepted February 12, 2019

Published March 30, 2019

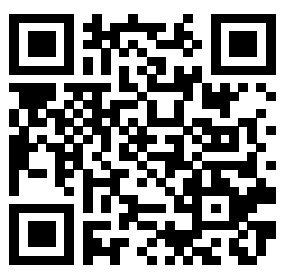

\begin{abstract}
Purpose: We developed a glutathione-containing screening (GCS) system capable of confirming toxicity at the substance screening stage aimed at reducing the time and cost of the cosmetic raw material development stage. Methods: Based on genotoxicity testing, a GCS system, comprising a direct and indirect system, was developed to reduce the time and cost to identify toxicity during the screening of candidate cosmetic substances. Toxicity potential was confirmed by identifying changes in the content of total glutathione (GSH), which conjugates only toxic substances, and those in the glutathione disulfide (GSSG)/GSH ratio. Results: Heptanal, a positive control substance in skin irritation tests, showed a decrease in total GSH and was identified as a direct-acting toxicant. Eugenol, a positive control substance in skin sensitization tests, showed a decrease in total GSH and an altered GSSG/GSH ratio and was identified as an indirect-acting toxicant. Conclusion: The GCS system could identify toxicity characteristics of skin irritation and sensitization. However, more positive chemicals are required to induce skin irritation or sensitization to challenge a chemical's toxic classification such as irritation or sensitization according to the GCS system, direct and indirect systems.
\end{abstract}

Keywords: Glutathione, GCS system, Genotoxicity test, Heptanal, Eugenol

\section{Introduction}

화장품의 안전성에 대한 자료를 생산하기 위해서 동물모델이 많이 사용되어 왔지만, 전 세계적으로 실험동물의 생명윤리 논란 이 일어나면서 동물실험을 반대하는 목소리가 커지고 있다(Son $\& \mathrm{Seo}, 2012)$. 동물실험에 대한 윤리적 문제가 대두되면서 유럽 연합(European Union, EU)에서는 2003년 화장품법을 개정 후 단계적으로 2013년까지 화장품의 원료 및 제품의 안전성 확보 를 위하여 검증된 대체시험법(alternatives-animal testing)이 있는 경우 동물실험을 금지하는 법안을 발표하였다. 이러한 구 체적 흐름과 더불어 우리나라에서도 화장품법 제 15 조 2 항에 따 라 2017년부터 동물실험을 통해 안전성이 확인된 화장품 원료 및 제품에 대하여 유통 및 판매가 전면금지 되었다(Lee et al., 2018).

이러한 국내외적 흐름에 따라 동물실험을 대신하는 다양 한 대체시험법이 개발이 되고 있다. 화장품의 안전성을 평가
하기 위해 우선적으로 요구되는 피부자극성 및 피부감작성에 대한 대체시험법도 개발되고 있다(Hong et al., 2014; Lee et al., 2016; Lee et al., 2014; Yang et al., 2015; Kim, 2011). 피부감작성평가 대체시험법으로 마우스를 이용한 local lymph node assay (LLNA) 시험법과 LLNA 시험법을 개선한 LLNA:developed by Daicel Chemical Industries, Ltd. (DA) 법과 LLNA:5-Bromo-2'-Deoxyuridine (BrdU) enzymelinked immunosorbent assay (ELISA)법이 국제적으로 인증되 고 있다(OECD, 2010a; OECD, 2010b; OECD, 2018). 그리고 피부자극성평가 대체시험법으로는 OECD test guideline 429 등 이 제시되었다(OECD, 2010a). 그러나 이러한 대체시험법의 개 발에도 불구하고 인체피부모델의 경우, 국내에서 생산의 문제, 제품자체의 고비용 등의 in vivo 상황을 온전히 재현할 수 없는 in vitro 시험의 한계가 지적되고 있다(Anadón et al., 2014). 특히 생체전환 과정인 생화학적 전환(biotransformation)을 통 해 생성된 친전자성대사체(electrophilic metabolite)와 생체 단 
백질의 결합에 의한 발생 기전이 설명되고 있어 생화학적 전환 유무는 피부의 감작성 및 자극성 예측에 대단히 중요하다(Park, 2010).

일반적으로 화학물질의 독성은 원물질(parent compound) 의 활성화(activation)에 기인한다(Park et al., 2014). 원물질 의 활성화란 독성을 유발하기 위해 세포 및 인체를 구성하는 거 대분자인 당, 단백질, $\mathrm{DNA}$ 그리고 지질 등과의 결합 능력이나 라디칼(radical)을 생성할 수 있는 능력을 의미한다(Park et al., 2014). 대부분 부식을 비롯하여 자극성 및 감작성 등의 피부손상 도 원물질의 활성화에 기인하다(Mercer et al., 2009; Madden et al., 2017; Weston et al., 2014). 활성화는 자연분해(natural decomposition) 및 cytochrome P450 등과의 효소에 의한 과 정인 생화학적 전환으로 이루어진다(Park et al., 2014). 이러 한 독성 유발의 활성화 원리가 동물실험이 아닌 유전독성시험의 in vitro 시험에 적용되고 있다. 유전독성시험에서는 $\mathrm{S} 9$ 분획(S9 fraction)의 존재 유무에 따라 직접법과 대사활성법(metabolic activation)으로 나뉘어 진다. 대사활성법은 대사에 관여하는 cytochrome P450을 포함하고 있어 효소에 의한 생체활성화 (bioactivation)이다. 반면에 직접법에서는 S9 분획이 없어 가수 분해 등과 같은 자연분해에 의한 활성화가 이루어진다. 즉, 유전 독성시험에서 대사활성법과 직접법은 화학물질의 활성화를 유도 하여 DNA에 결합 또는 상호작용을 유도하여 돌연변이를 유도하 는 시험법으로 대체시험법의 선구적인 시험법이라고 할 수 있다.

이와 같이 유전독성시험에서 응용된 화학물질의 활성화 원리 를 피부의 자극성(irritation) 및 감작성(sensitization) 유도에서 도 적용하여 대체시헙법의 개발이 가능하다. 예를 들어 피부자극 물질은 피부를 구성하고 있는 각질층(stratum corneum)의 표면 단백질과 상호작용하여 구조물의 파괴와 변성을 유도하여 피부 자극을 유발하는데 이 역시 활성화를 통해 이루어진다(Agner \& Serup, 1990; Barel et al., 2014; Nizio 1 - Łukaszewska et al., 2017; Rhein et al., 2006). 또한 피부감작물질도 활성화를 통해 피부 또는 체내 단백질과 결합하여 항원으로 전환되는 햅텐 화(haptenization) 형성을 통해 감작을 유도한다(Dupuis et al., 1980; Patlewicz et al., 2001). 이러한 활성화에 의한 피부의 자극성 및 감작성을 유도하는 물질 탐색을 위한 시험법 개발을 위해 유전독성시험의 기본 원리 및 방법이 고려될 수 있다. 그러 나 활성화 기전은 동일하지만 유전독성시험에서 활성화의 결과에 의한 DNA 손상 및 결과를 DNA가 아닌 지질 또는 단백질과의 결 합을 통해 발생하는 피부의 자극성 및 감작성을 유도하는 잠재력 을 가진 물질로 판정하기는 어렵다. 특히 활성화의 강도에 따라 친전자성대사체는 단백질과 결합하는 경성 친전자성대사체 $(\mathrm{soft}$ electrophilic metabolite), 그리고 DNA와 결합하는 중성 친전자 성대사체(hard electrophilic metabolite)로 분류되는 것으로 알 려졌다(Park, 2010; LoPachin \& DeCaprio, 2005). 피부 자극
성 및 감작성 유도는 단백질과 상호작용을 통해 이루어지기 때문 에 대부분의 자극물질(irritants) 및 감작물질(sensitization)은 경성 친전자성대사체에 속한다.

본 연구에서는 유전독성시험 in vitro 시스템에 단백질-유사 기능으로 기대되는 글루타치온(glutathione, GSH)를 추가하여 화학물질의 피부의 자극성 및 감작성을 탐색할 수 있는 글루타치 온-함유 탐색 시스템(glutathione-containing screen system, GCS system)을 개발하는 것이 목적이다. GSH는 유기성 외인성 물질(organic xenobiotics)의 독성대사체(toxic metabolites)를 제거하는 생체 내 유일한 물질인데 3 개의 아미노산인 글루탐산 ( $\mathrm{Y}$-glutamic acid), 시스테인(cysteine)과 글리신(glycine) 등으 로 구성된 트리펩티드(tripeptide)이다. GSH는 독성물질을 제거 하는 포합반응(conjugation)뿐만 아니라 항산화적 방어 및 세포 증식조절 등 세포 내에서 다양한 기능을 수행한다. 이와 같은 다 양한 기능을 가진 GSH를 이용하여 OECD guideline 439의 피 부자극성시험 및 $\mathrm{OECD}$ guideline 429 등의 피부감작성시험에 서 응용되는 양성대조물질과 GSH 반응 결과를 통해 GCS 시스 템(GCS system)을 개발한다. 특히 GCS 시스템은 시험물질의 생화학적 전환 및 자연분해에 의한 활성화를 구분하기 하기 위한 직접시스템(direct system)과 간접시스템(indirect system) 등 의 2 시스템으로 구성된다. 간접시스템에는 $\mathrm{S} 9$ 분획이 포함하는 데 이 분획은 랫드의 미크로좀(microsome) 분획으로 화학물질의 생화학적 전환을 유도하는 cytochrome P450을 포함하고 있다 (Park, 2010). 따라서 직접시스템은 시험물질이 자연분해에 의 해 활성화되며 간접시스템에서는 생화학적 전환에 의해 활성화되 며 직접시스템 및 간접시스템 각각은 유전독성시험에서 직접법과 대사활성법과 동일한 원리에 $\mathrm{GSH}$ 가 추가된 시스템이 된다. 이 들 두 시스템에서 활성화가 이루어진 시험물질은 GSH의 변화를 유도하며 이를 측정하는 것이 피부의 자극성 및 감작성 잠재성을 탐색하는 기본 원리가 된다. GSH의 변화는 단백질과 결합하여 GSH 총량(total GSH)의 감소를 비롯하여 GSH 산화에 의한 산 화된 GSH 2 개의 결합된 형태인 GSSG의 증가 등의 2 가지이다.

\section{Methods}

\section{1. 세포배양 및 GCS system 구성}

실험에 사용된 heptanal, eugenol, dimethyl sulfoxide (DMSO)은 Sigma-Aldrich (USA)로부터 구입하였다. S9 분 획은 MOLTOX (Boone, USA)로 부터 구입하였다. Fetal bovine serum (FBS), penicillin, streptomycin, Dulbecco's Modified Eagle Medium (DMEM)배지는 Gendepo (USA)로 부터 구입하였다. 햄스터 난소 세포주인 $\mathrm{CHO}-\mathrm{K} 1$ 세포는 한국 세포주 은행(Korean Cell Line Bank, Korea)에서 분양을 받았 
다. $\mathrm{CHO}-\mathrm{K} 1$ 세포는 $10 \% \mathrm{FBS}, 100 \mathrm{U} / \mathrm{mL}$ penicilin, $100 \mu \mathrm{g} /$ $\mathrm{mL}$ streptomycin을 함유하는 DMEM 배지를 사용하여 $5 \%$ 의 $\mathrm{CO}_{2}, 37^{\circ} \mathrm{C}$ 환경에서 배양하였다. GCS 시스템은 시험물질의 생 화학적 전환 및 자연분해에 의한 활성화를 구분하기 하기 위한 직접시스템과 간접시스템 등의 2 system으로 구성된다(Table 1). 또한 GCS 시스템 구성에 요구되는 glutathione peroxidase (GPX), superoxide dismutase (SOD) 및 glutathione (GSH)는 Sigma-Aldrich에서 구입하였다.

\section{2. 세포 및 배양액에서의 total GSH 및 GSSG/GSH ratio 측정}

$\mathrm{GCS}$ 시스템 개발을 위해 시험물질에 의한 $\mathrm{GSH}$ 의 변화와 GSSG/GSH 비의 변화를 배양세포 및 세포 배양액 내에서 확인 하였다. 먼저 세포 내에서 측정은 $\mathrm{CHO} \mathrm{K1}$ 세포를 $4 \times 10^{5}$ cells/ $\mathrm{mL}$ 으로 분주한 후 $24 \mathrm{~h}$ 배양 후 시험물질로 처리하여 이루어졌 다. FBS free S9 분획이 포함되어있는 군(간접시스템)과 S9 분 획이 없는 군(직접시스템)에 각각 시험물질을 $0.78 \mu \mathrm{L} / \mathrm{mL}$ 농도 로 처리하였다. $6 \mathrm{~h}$ 동안 처리한 후, $\mathrm{PBS}$ 로 희석해준 다음, 세포 를 긁어 모아 $4^{\circ} \mathrm{C}, 1000 \mathrm{~g}$ 에서 $15 \mathrm{~min}$ 동안 원심분리를 하였다. 상층액을 제거한 후 2-(N-morpholino) ethanesulfonic acid (MES) buffer를 넣고 $4^{\circ} \mathrm{C}$ 에서 $10,000 \times \mathrm{g}$ 에서 $20 \mathrm{~min}$ 원심분리 를 하였다. 상층액을 Cayman glutathione assay kit (Cayman Chemical, USA)를 이용하여 GSH 총용량과 GSSG/GSH 비를 측정하였다. 또한 세포를 추가하지 않고 배양액만 이용하여 $\mathrm{GSH}$ 총량과 GSSG/GSH 비를 측정하였다. GCS 시스템은 시험물질을 $2 \mu \mathrm{L} / \mathrm{mL}$ 농도로 $3 \mathrm{~h}$ 처리한 후에 metaphosphoric acid (MPA) 와 $1: 1$ 로 희석한 후 $4^{\circ} \mathrm{C}$ 에서 $10,000 \times \mathrm{g}$ 에서 $20 \mathrm{~min}$ 원심분리 하였다. 상층액을 Cayman glutathione assay kit를 이용하여 $\mathrm{GSH}$ 총량, GSSG/GSH 비를 측정하였다.

\section{3. 시험물질}

$\mathrm{GCS}$ 시스템 개발의 목적은 화학물질의 피부 자극성 및 감작성 을 간단하게 in vitro로 확인하는 탐색 방법을 개발하는 것이기 때문에 기존의 방법으로 확인된 자극성 및 감작성을 유도하는 물 질에 의한 GSH 총량과 GSSG/GSH 비의 변화가 확인되어야 한 다. 따라서 본 연구에서 선택된 시험물질은 실제적으로 피부자 극성시험인 OECD test guideline 439에서 응용되는 양성대조 물질인 heptanal (OECD, 2013)과 피부감작성시험 OECD test guideline 429에서 응용되는 양성대조물질인 eugenol (OECD, 2010a) 등 두 가지 물질을 사용하였다.

\section{4. 통계처리}

통계처리는 one-way analysis variance (ANOVA) 및 Student's $t$-test analysis를 이용하여 분석하였으며 $p$-value는 0.05 이하일 때 유의한 것으로 판단하였다.

\section{Results}

\section{Heptanal의 total GSH 및 GSSG/GSH ratio 측정}

Table 2는 피부자극물질인 heptanal 처리에 의해 세포 내 $\mathrm{GSH}$ 총량의 변화를 나타낸 것이다. 대조군의 S9 분획이 없는 $\mathrm{S} 9$ (-)에서는 $5.51 \pm 0.033 \mu \mathrm{M}$, 그리고 $\mathrm{S} 9$ 분획이 존재하는 $\mathrm{S} 9$ (+)에서는 $5.76 \pm 0.044 \mu \mathrm{M}$ 의 $\mathrm{GSH}$ 총량으로 확인되었다. 반면 에 heptanal인 경우, $\mathrm{S} 9(-)$ 은 $4.42 \pm 0.053 \mu \mathrm{M}$ 그리고 $\mathrm{S} 9(+)$ 은 $5.55 \pm 0.048 \mu \mathrm{M}$ 의 GSH 총량으로 확인되었다. Heptanal 처 리에 의해 S9 분획의 존재 유무와 상관없이 유의하게 GSH 총 량이 감소하였다 $(p<0.05)$. 또한, heptanal 처리에 의해 세포 내

\section{Table 1. Content of the GCS system}

\begin{tabular}{lcc}
\hline & Direct system & Indirect system \\
Media & DMEM & DMEM \\
GSH & $10 \mu \mathrm{M}$ & $10 \mu \mathrm{M}$ \\
GPX & $30 \mathrm{U} / \mathrm{mg}$ & $30 \mathrm{Umg}$ \\
SOD & $50 \mathrm{mU} / \mathrm{mg}$ & $50 \mathrm{mU} / \mathrm{mg}$ \\
S9 fraction & $X$ & 0 \\
\hline
\end{tabular}

GCS, glutathione-containing screen; DMEM, Dulbecco's modified eagle medium which include $100 \mathrm{U} / \mathrm{mL}$ penicillin and $100 \mu \mathrm{g} / \mathrm{mL}$ streptomycin; GSH, glutathione; GPX, glutathione peroxidase; SOD, superoxide dismutase; X, not including; 0, including.

Table 2. Changes in intracellular total GSH and GSSG/GSH ratio by heptanal

(Unit: $\mu \mathrm{M})$

\begin{tabular}{llccc}
\hline & \multicolumn{2}{c}{ total GSH } & \multicolumn{2}{c}{ GSSG/GSH ratio } \\
\cline { 2 - 5 } & $\mathrm{S} 9(-)$ & S9 $(+)$ & S9 (-) & S9 (+) \\
DMSO & $5.51 \pm 0.033$ & $5.76 \pm 0.044$ & $0.78 \pm 0.060$ & $0.69 \pm 0.023$ \\
Heptanal & $4.42 \pm 0.053^{* * *}$ & $5.55 \pm 0.048^{*}$ & $0.82 \pm 0.036$ & $0.71 \pm 0.036$ \\
\hline
\end{tabular}

Data are presented as mean \pm standard deviation. CHO-K1 cells were treated with $0.78 \mu \mathrm{L} / \mathrm{mL}$ of heptanal, and DMSO was used as control. There was a significant decrease in total GSH in both direct and indirect systems than in the control group $\left({ }^{*} p<0.05,{ }^{* * *} p<0.001\right)$. There was no significant difference in GSSG/GSH ratio between the direct and indirect systems. GSH, glutathione; GSSG, glutathione disulfide; DMSO, dimethyl sulfoxide. 
의 GSSG/GSH 비는 대조군의 경우, $0.78 \pm 0.060$, S9 (+)은 $0.69 \pm 0.023$ 으로 관찰되었다. 또한 heptanal 처리군의 경우에 $\mathrm{S} 9$ (-) $0.82 \pm 0.036$ 그리고 $\mathrm{S} 9$ (+)는 $0.71 \pm 0.036$ 으로 관찰 되었다. S9 분획 유무에 따라 heptanal 처리에 의한 세포 내의 $\mathrm{GSSG} / \mathrm{GSH}$ 비에서 유의적인 변화가 관찰되지 않았다.

\section{Eugenol의 total GSH 및 GSSG/GSH ratio 측정}

피부감작물질인 eugenol을 세포에 처리 하였을 때에 GSH 총 량의 변화가 Table 3 에 확인되었다. 대조군에서 S9 (-)은 5.51 $\pm 0.036 \mu \mathrm{M}$ 그리고 $\mathrm{S} 9(+)$ 은 $5.67 \pm 0.079 \mu \mathrm{M}$ 으로 관찰되었 다. Eugenol 처리군의 경우에 $\mathrm{S} 9(-)$ 에서 $5.33 \pm 0.053 \mu \mathrm{M}$ 그 리고 $\mathrm{S} 9$ (+)에서는 $5.13 \pm 0.025 \mu \mathrm{M}$ 으로 관찰되었다. $\mathrm{GSH}$ 총 량의 변화를 확인해 본 결과, $\mathrm{S} 9$ 분획이 존재하는 경우에서 유의 적인 감소가 관찰되었다 $(p<0.001)$. 또한 eugenol 처리에 따른 GSSG/GSH 비의 변화를 확인 해본 결과(Table 3 ), 대조군의 경 우 S9 (-)은 $1.15 \pm 0.030, \mathrm{~S} 9$ (+)은 $1.18 \pm 0.076$ 으로 관찰되 었다. Eugenol 처리군의 경우, S9 (-)은 $1.22 \pm 0.029, \mathrm{~S} 9(+)$ 은 $1.36 \pm 0.022$ 으로 관찰되었다. 그리고 $\mathrm{GSSG} / \mathrm{GSH}$ 비의 변화 를 확인해본 결과, $\mathrm{S} 9$ 분획이 존재하는 경우에 유의적인 증가가 확인되었다 $(p<0.001)$.

\section{GCS 시스템}

GCS 시스템에서는 기존의 유전독성시험에서 세포를 제거하
고 $\mathrm{GPX}$ 와 $\mathrm{SOD}$ 를 첨가한 후 $\mathrm{GSH}$ 총량과 $\mathrm{GSSG} / \mathrm{GSH}$ 비의 변 화를 확인하였다. Table 4는 GCS 시스템에 heptanal 처리에 따 른 GSH 총용량의 변화를 확인한 것이다. 대조군의 경우 S9 (-) 은 $82.88 \pm 1.016 \mu \mathrm{M}$ 그리고 $\mathrm{S} 9(+)$ 은 $74.42 \pm 4.830 \mu \mathrm{M}$ 으

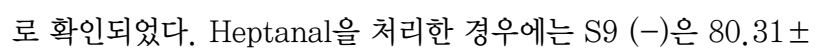
$0.751 \mu \mathrm{M}$ 그리고 $\mathrm{S} 9(+)$ 은 $74.23 \pm 3.730 \mu \mathrm{M}$ 로 확인되었다. 따라서 세포 내의 변화와 달리 GCS 시스템에서는 S9 분획이 없 는 군에서만 유의적인 감소가 관찰되었다 $(p<0.05)$. 또한 $\mathrm{GCS}$ 시스템을 통해 heptanal 처리에 따른 GSSG/GSH 비의 변화를

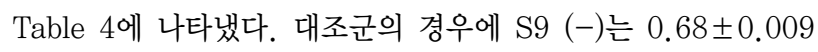
그리고 $\mathrm{S} 9(+)$ 는 $0.68 \pm 0.002$ 으로 확인되었다. Heptanal 처리 군의 경우에는 $\mathrm{S} 9(-)$ 는 $0.68 \pm 0.002$ 그리고 $\mathrm{S} 9(+)$ 는 $0.69 \pm$ 0.009 으로 확인되었다. 결과적으로 세포내의 변화와 같이 S9 분 획 유무에 따라 유의적인 변화는 관찰되지 않았다.

Table 5에서는 피부감작물질인 eugenol을 GCS 시스템을 통 하여 GSH 총량의 변화가 확인되었다. 대조군의 경우에는 S9 (-)은 $67.61 \pm 1.074 \mu \mathrm{M}$ 그리고 $\mathrm{S} 9(+)$ 은 $71.26 \pm 1.253 \mu \mathrm{M}$ 으로 관찰되었다. Eugenol 처리군의 경우에 S9 (-)은 $67.80 \pm$ $1.129 \mu \mathrm{M}$ 그리고 $\mathrm{S} 9$ (+)은 $67.42 \pm 2.151 \mu \mathrm{M}$ 으로 관찰되었다. GCS 시스템으로 GSH 총량의 변화를 확인해본 결과, S9 분획이 존재하는 군에서 유의적인 감소가 확인되었다 $(p<0.05)$.

GCS 시스템을 통해 eugenol 처리에 따른 GSSG/GSH 비의 변화를 확인하였다(Table 5). 대조군의 경우, S9 (-)은 $0.26 \pm$

Table 3. Changes in intracellular total GSH and GSSG/GSH ratio by eugenol

\begin{tabular}{lcccc}
\hline & \multicolumn{3}{c}{ total GSH } & \multicolumn{2}{c}{ GSSG/GSH ratio } \\
\cline { 2 - 5 } & $\mathrm{S} 9(-)$ & $\mathrm{S} 9(+)$ & $\mathrm{S} 9(-)$ & $\mathrm{S} 9(+)$ \\
DMSO & $5.51 \pm 0.036$ & $5.67 \pm 0.079$ & $1.15 \pm 0.030$ & $1.18 \pm 0.076$ \\
Eugenol & $5.33 \pm 0.053$ & $5.13 \pm 0.025^{* * *}$ & $1.22 \pm 0.029$ & $1.36 \pm 0.022^{* * *}$ \\
\hline
\end{tabular}

Data are presented as mean \pm standard deviation. CHO-K1 cells were treated with $0.78 \mu \mathrm{L} / \mathrm{mL}$ of eugenol, and DMSO was used as a control. There was a significant decrease in total GSH in the indirect system compared with the control group $\left({ }^{* * *} p<0.001\right)$, and a significant increase in intracellular GSSG/GSH ratio in the indirect system $\left({ }^{* * *} p<0.001\right)$.

Table 4. Changes in total GSH and GSSG/GSH ratio by heptanal in the GCS system

\begin{tabular}{lcccc} 
& \multicolumn{3}{c}{ total GSH } & \multicolumn{2}{c}{ GSSG/GSH ratio } \\
\cline { 2 - 5 } & $\mathrm{S9}(-)$ & $\mathrm{S} 9(+)$ & $\mathrm{S} 9(-)$ & $\mathrm{S} 9(+)$ \\
DMSO & $82.88 \pm 1.016$ & $74.42 \pm 4.830$ & $0.68 \pm 0.009$ & $0.68 \pm 0.002$ \\
Heptanal & $80.31 \pm 0.751^{*}$ & $74.23 \pm 3.730$ & $0.68 \pm 0.002$ & $0.68 \pm 0.009$ \\
\hline
\end{tabular}

Data are presented as mean \pm standard deviation. The GCS system was treated with $0.2 \mu \mathrm{L} / \mathrm{mL}$ heptanal. There was a significant decrease in total GSH in the direct system ( $\left.{ }^{*} p<0.05\right)$, but no significant difference in GSSG/GSH ratio in both direct and indirect systems. GSH, glutathione; GSSG, glutathione disulfide; GCS, Glutathione-Containing Screen; DMSO, dimethyl sulfoxide.

Table 5. Changes in total GSH and GSSG/GSH ratio by eugenol in the GCS system

\begin{tabular}{lcccc} 
& \multicolumn{3}{c}{ total GSH } & \multicolumn{2}{c}{ GSSG/GSH ratio } \\
\cline { 2 - 5 } & $\mathrm{S} 9(-)$ & $\mathrm{S} 9(+)$ & $\mathrm{S} 9(-)$ & $\mathrm{S} 9(+)$ \\
DMSO & $67.61 \pm 1.074$ & $71.26 \pm 1.253$ & $0.26 \pm 0.006$ & $0.27 \pm 0.006$ \\
Eugenol & $67.80 \pm 1.129$ & $67.42 \pm 2.151^{*}$ & $0.23 \pm 0.002$ & $0.35 \pm 0.036^{* *}$ \\
\hline
\end{tabular}

Data are presented as mean \pm standard deviation The GCS system was treated with $0.2 \mu \mathrm{L} / \mathrm{mL}$ eugenol. There was a significant decrease in total GSH in the indirect system ( $\left.{ }^{*} p<0.05\right)$ and a significantly increase in GSSG/GSH ratio in the indirect system $\left({ }^{* *} p<0.01\right)$. GSH, glutathione; GSSG, glutathione disulfide; GCS, Glutathione-Containing Screen; DMSO, dimethyl sulfoxide. 


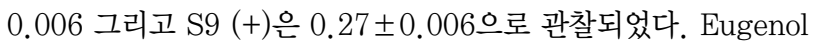
처리군의 경우에 $\mathrm{S} 9$ (-)은 $0.23 \pm 0.002$ 그리고 $\mathrm{S} 9$ (+)은 0.35 \pm 0.036 으로 관찰되었다. 세포 내의 변화와 동일하게, S9 분획 이 포함되어 있는 군에서 유의적인 GSSG/GSH 비의 증가가 관 찰되었다 $(p<0.01)$

\section{Discussion}

\section{1. 화학물질의 독성 유발을 위한 2 가지 활성 기전}

피부의 자극성 및 감작성을 포함하는 모든 독성은 생체를 구 성하는 거대분자인 단백질, 당, 지질 그리고 DNA 등과 상호작 용을 통해 이루어지며 이는 화학물질의 활성화를 통해 유도된 다. 이러한 화학물질에 의한 초기 상호작용을 독성작용기전의 일종(mode of action, $\mathrm{MOA}$ )이라고 하는데 $\mathrm{MOA}$ 의 시작은 활 성화이며 활성화는 2 가지 경로를 통해 이루어진다(Betharia et al., 2014; Park, 2010; Park et al., 2014). 활성화의 2 가 지 경로는 생화학적 전환인 직접-작용 독성물질(direct-acting toxicants)과 간접-작용 독성물질(indirect-acting toxicants) 로 구분된다. 직접-작용 독성물질은 제 1 상반응(phase I reaction)과 제2상반응(phase II reaction)의 생화학적 전환 과정이 없이 원물질(parent compound) 자체 또는 자연분해 (natural decomposition)를 통해 독성을 유발하는 물질을 의미 한다. 반면에 제 1 상반응과 제 2 상반응의 생화학적 전환 과정을 통해 활성화가 이루어지고 결과적으로 생성되는 활성중간대사체 (reactive intermediates)를 유발하는 물질을 간접-작용 독성물 질이라고 한다. 피부의 자극성 및 감작성 물질은 직접-작용 독 성물질 또는 간접-작용 독성물질 중 하나가 되지만 독성의 $\mathrm{MOA}$ 측면에서 피부 자극성 및 감작성은 특정 독성물질로 구분될 수 있을 것으로 추정할 수 있다. 이에 대한 이해는 자극성 및 감작성 물질의 탐색을 위한 대체시험법 개발에 중요한 논리적 근거를 제 시하는데 역할을 할 것으로 사료된다.

\section{GSH 기능과 GCS 시스템의 개발 원리}

위 활성화의 2 가지 경로에 의해 활성화는 in vitro 유전독성 시험이 직접법과 대사활성법을 구분하여 유전독성시험이 이루어 지는 것의 논거가 된다. 즉 직접-작용 독성물질은 cytochrome $\mathrm{P} 450$ 효소계가 포함되어 있는 S9 분획이 없는 in vitro 유전 독성시험법의 직접법을 통해 DNA 손상 및 돌연변이를 유도하 는 물질이다. 반면에 간접-작용 독성물질은 $\mathrm{S} 9$ 분획이 있는 in vitro 유전독성시험법을 통해서만 유전손상을 유도하는 물질이 다(OECD, 1997; OECD, 2016). 이러한 원리를 이용하여 본 연 구에서는 활성화된 직접-작용 독성물질과 간접-작용 독성물질 이 $\mathrm{GSH}$ 와 결합 또는 작용을 통화 변화 즉, $\mathrm{GSSG} / \mathrm{GSH}$ 의 변화
를 자극성 및 감작성 물질을 탐색하여 대체독성시험의 가능성과 이들 물질들의 초기 탐색 방법을 개발하고자 시도하였다. 본 연 구에서 GSH을 사용한 이유는 생체에서 직접-작용 독성물질 및 직접-작용 독성물질 등의 독성대사체를 제거하는 유일한 물질 이 GSH이라는 것이다. GSH은 3개의 아미노산인 $\mathrm{\gamma}$-glutamic acid, cysteine 및 glycine으로 구성된 tripeptide인데 3개의 아 미노산 중 cysteine 잔기인 $-\mathrm{SH}$ group의 강력한 전자공여력 (electron-donating capacity)에 의해 독성대사체 또는 독성 물질이 제거된다. 만약에 GSH가 부족하다면 단백질의 $-\mathrm{SH}$ 와 결합하여 독성을 유발하게 된다. 특히 $\mathrm{GSH}$ 는 $-\mathrm{SH}$ 를 함유 한 cysteine이 간세포에서만 합성되어 간이 GSH 합성의 유일한 기관이며 해독기관이 중심이 되는 이유이다 $(\mathrm{Lu}, 2009)$. 따라서 $\mathrm{GSH}$ 의 $-\mathrm{SH}$ 에 기인하여 활성화로 전환되는 물질을 탐색하는데 가장 민감한 물질이며 본 연구에서 피부의 자극성 및 감작성 물 질을 탐색하는데 적절한 방안이라고 할 수 있다. 특히 피부의 자 극성 및 감작성 유도에서 피부를 구성하고 있는 표면 단백질을 비롯하여 피부는 체내 단백질과의 결합을 통한 hapten 형성처 럼 단백질과의 상호작용을 통해 이루어지기 때문이다(Agner et al., 1990; Barel et al., 2014; Rhein et al., 2006; Nizio łŁukaszewska et al., 2017; Dupuis et al., 1980; Patlewicz et al., 2001). 이와 같은 이론적 기반을 바탕으로 화학물질에 의 한 피부의 자극성 및 감작성을 초기 및 간단하게 탐색하는 방법 을 개발하기 위해 in vitro 유전독성시험 시스템을 변형한 GCS 시스템을 고안하였다. 또한 GCS 시스템에서 세포 분획 및 배양 액에서 잘 알려진 피부 자극성과 감작성 유도물질인 heptanal과 eugenol에 의한 GSH 총용량과 GSSG/GSH 비의 변화를 직접 시스템과 간접시스템을 통해 확인하였다.

먼저 OECD test guideline 439에서 응용되는 자극성 양성 대조물질인 heptanal에 의한 세포 내에서 GSSG/GSH 비를 확 인한 결과, GSSG/GSH 비의 유의한 변화가 관찰되지 않았다 (OECD, 2013). 일반적으로 독성물질에 의한 GSSG/GSH 비 는 증가하는데 이는 독성물질이 산화적 스트레스(oxidative stress)의 유발에 기인한다(Jones, 2002; Winterbourn et al., 2008). 특히 화학물질-유도성 산화적 스트레스는 유해활성산소 (reactive oxygen species, ROS)을 유발하거나 유기성 라디칼 (organic radical)로의 활성화에 기인한다(Bandyopadhyay et al., 1999; Yin et al., 2011). 따라서 heptanal은 산화적 스트 레스 유발에 의한 자극성을 유발하지 않는 것으로 추정된다. 반 면에 heptanal에 의한 GSH 총량을 확인한 결과, 직접시스템과 간접시스템 등의 모두에서 통계적으로 유의하게 감소되었다. 이 러한 감소는 $\mathrm{GSH}$ 와 heptanal과 결합으로 free-GSH의 감소를 의미한다. 그러나 무엇보다도 중요한 것은 직접시스템과 간접시 스템 등의 두 시스템 모두에서 heptanal에 의한 GSH 감소를 어 떻게 이해할 것 인가이며 이는 GCS 시스템의 판정기준을 설정 
하는데 중요한 자료가 된다. 직접시스템과 간접시스템에서 중요 한 차이는 $\mathrm{S} 9$ 분획의 유무이며 공통점은 가수분해와 같은 자연 분해가 발생할 수 있는 수용액 상황이다. 따라서 직접시스템과 간접시스템에서의 GSH 감소는 생화학적 전환이 아닌 자연분해 에 의한 heptanal의 활성화에 기인하는 것으로 추정된다. 결론 적으로 heptanal은 직접-작용물질이며 피부의 수분 상황에서 활성화 되어 단백질 등과 작용하여 피부 자극성을 유도할 수 있 는 잠재적 물질로 추정된다. 실제적으로 생화학적 전환이 없이 heptanoic acid 또는 pimelic acid로 전환되는 원물질 자체의 자연적인 활성화가 이루어지는 것으로 알려졌다(Golla et al., 2009). 특히 heptanal은 알데히드(aldehyde) 종류인데 활성화 를 통해 각질층의 장벽기능에 손상을 입히거나 탈지 및 단백질 변성을 통한 피부자극을 유발하는 직접-작용 피부자극성물질로 추정된다(Clayton \& Clayton, 1982; Welss et al., 2004).

OECD test guideline 429에서 응용되는 감작성 양성대조물 질인 eugenol에 의한 GSH 총량을 확인한 결과, 직접시스템이 아닌 간접시스템에서만 GSH 총량의 값이 유의하게 감소하였다 (OECD, 2010a). 이는 간접시스템에만 존재하는 S9 분획에 의 한 생화학적 전환의 결과로 eugenol의 활성화에 기인하는 것으 로 추정된다. 즉 생화학적 전환의 제 1 상반응을 수행하는 핵심 효소인 cytochrome P450에 의해 활성화되어 GSH 고갈을 유 도한 것으로 추정된다. 실제로 피부에 노출된 물질이 CYP1A1, CYP1B1, CYP2B6, CYP2E1, CYP3A 등의 cytochrome P450 에 의하여 생화학적 전환을 통해 단백질을 비롯하여 4 대 거대 분자와 결합하는 활성중간대사체(reactive intermediates)로 전환되는 것으로 확인되고 있다(Merk et al., 1996; Jugert et al., 1994; Khan et al., 1989). 또한 진피 및 표피에서 cytochrome P450에 의해 생성된 활성중간대사체는 단백질과 결합하여 항원으로 작용이 가능한 pro hapten으로 역할이 제 시되었다(Bergström et al., 2007; Götz et al., 2012). 이와 같이 합텐화(haptenization)가 이루어지면 항원제시세포에 의 해 기억되어 다시 노출 되면 T-cell을 통한 면역반응이 나타나 는 것으로 알려졌다(Ahmad \& Mukhtar, 2004; Kaplowitz, 2005; Reisinger et al., 2015; Son \& Seo, 2012). 이와 같 이 간접시스템에서 $\mathrm{GSH}$ 총용량의 감소는 eugenol의 활성화 에 기인하는 것으로 감작성의 간접-작용물질로 추정된다. 실 제로 eugenol는 사람의 케라틴 생성세포(keratinocyte)에 서 CYP1A1에 의한 생화학적 전환을 통해 활성중간대사체인 $p$-quinonemethide로 전환되어 GSH와 결합하는 것으로 알려 졌다(Thompson et al., 1990). 또한 간접시스템에서 GSH 고 갈뿐만 아니라 eugenol에 의해 GSSG/GSH 비도 증가되었다. 이는 생화학적 전환에 의해 eugenol의 활성중간대사체가 유해 활성산소에 의한 연쇄반응 또는 유기성 라디칼에 의한 산화-
환원반응을 유도하는 특성을 가진 종류로 추정된다. 생화학적 전환에 의한 활성중간대사체는 친전자성대사체(electrophilic metabolites)를 비롯하여 탄소-기원 라디칼(carbon-centered radical) 그리고 산화-환원활성종(redox-active species) 등 의 3 종류인데 이중 탄소-기원 라디칼과 산화-환원활성종인 GSSG/GSH 비를 증가시키는 연쇄반응 및 산화 환원반응(redox reaction)을 유도하는 것으로 알려졌다(Park, 2010). 이러한 측면에서 eugenol의 활성중간대사체인 $p$-quinonemethide 는 환원-산화반응 유도를 통해 산화적 스트레스를 유발하는 quinone 계열의 산화-환원활성종이라고 할 수 있다. 따라서 본 연구에서 확인된 eugenol에 의한 GSSG/GSH 비의 증가는 $p$-quinonemethide의 산화 환원반응에 기인하는 것으로 추정 된다. 특히 산화-환원반응은 산화적 스트레스를 유도하고 이에 발생하는 유해활성산소는 GSH의 산화를 촉진시켜 GSH 산화 형인 GSSG의 발생을 증가시킨다. 따라서 eugenol은 생화학적 전환에 의해 활성화되어 GSH 총량의 감소뿐만 아니라 GSSG/ $\mathrm{GSH}$ 비도 증가시키는 탄소-기원 라디칼 또는 산화-환원활성 종으로 추정되는 간접-작용 피부감작성물질로 사료된다. 이 와 같은 결과는 세포를 포함하는 GCS 시스템뿐만 아니라 세포 가 없는 배양액으로 구성된 GCS 시스템의 직접시스템과 간접시 스템에서 heptanal과 eugenol에 의한 GSH 총용량과 GSSG/ GSH 비에서도 유사하였다. 이는 세포 유무와 상관이 없이 GCS 시스템의 개발이 가능하다는 것을 의미한다.

\section{GCS 시스템의 피부접촉물질에 대한 응용}

본 연구에서 모든 독성물질이 활성화를 통해 체내 거대분자와 의 결합을 통해 독성을 유발하는 $\mathrm{MOA}$ 와 생체 내에서 유일하게 독성물질을 제거하는 물질이 GSH이라는 사실을 기반으로 피부 의 자극성 및 감작성 물질의 in vitro 탐색을 위한 새로운 방안 인 GCS 시스템의 개발이 시도되었다. 특히 GCS 시스템에 의한 물질의 자극성 및 감작성 탐색 가능성을 증명하기 위해 $\mathrm{OECD}$ test guideline 439 및 429 (OECD, 2013; OECD, 2010a)에 서 사용되는 양성대조물질인 heptanal과 eugenol이 사용되었 다. 이러한 시도의 결과를 통해 자극성 양성물질인 heptanal은 직접시스템 및 간접시스템 모두에서 GSH 총량의 감소가 유도 되어 자연분해에 의한 활성화가 이루어지는 직접-작용 물질로 추정되었다. 반면에 감작성 양성물질인 eugenol은 간접시스템 에서만 GSH 총량의 감소와 GSSG/GSH 비의 증가를 유도하였 다. 이는 eugenol의 활성화는 효소 특히 cytochrome P450 시 스템에 의해 이루어지는 간접-작용 물질로 추정된다. 이와 같 이 heptanal과 eugenol의 GCS 시스템에서 GSH 변화를 통해 영향을 통해 피부의 자극성 및 감작성의 탐색 가능성이 확인되 었다. 이는 원물질의 자연분해 또는 생화학적 전환을 통한 활성 
화에 의한 $\mathrm{GSH}$ 영향으로 추정되는데 이러한 $\mathrm{GSH}$ 에 대한 영향 이 자극성과 감작성 물질을 어떻게 구분할 수 있는가를 GCS 시 스템에서 직접적인 추정은 어렵다. 그러나 일반적으로 피부 자 극성은 노출 후 $24 \mathrm{~h}$ 이내에 자연분해에 의해 발생하는 급성적 특성이 있지만 피부 감작성은 피부 접촉 후 체내 혈관계로 유입 그리고 합텐화 등의 과정에서 자연분해보다 생화학적 전환에 의 해 유발되는 경향이 있는 것으로 추정된다(Bergström et al., 2007; Götz et al., 2012). 이러한 측면을 고려할 때 자극성물 질은 직접시스템, 그리고 감작성물질은 간접시스템에서 $\mathrm{GSH}$ 에 대한 영향이 클 것으로 추정된다. 그러나 GCS 시스템을 통해 더 많은 피부 자극성 및 감작성 양성물질의 활성화에 대한 경향성 을 확인할 필요성이 있다.

\section{Conclusion}

생체 내에서 유일하게 독성물질을 제거하는 물질이 GSH이라 는 사실을 기반으로 피부의 자극성 및 감작성 물질의 in vitro 탐색을 위한 새로운 방안인 GCS 시스템의 개발이 시도되었다. 특히 GCS 시스템에 의한 물질의 자극성 및 감작성 탐색 가능성 을 증명하기 위해 OECD test guideline 439 및 429에서 제시 되어 있는 양성대조물질인 heptanal과 eugenol이 사용되었다. 이러한 시도의 결과를 통해 자극성 양성물질인 heptanal은 직 접시스템 및 간접시스템 모두에서 $\mathrm{GSH}$ 총량의 감소가 유도되 어 자연분해에 의한 활성화가 이루어지는 직접-작용 물질로 추 정되었다. 반면에 감작성 양성물질인 eugenol은 간접시스템에 서만 GSH 총량의 감소와 GSSG/GSH 비의 증가를 유도하였 다. 이는 eugenol의 활성화는 효소 특히 cytochrome P450 시 스템에 의해 이루어지는 간접-작용 물질로 추정된다. 이와 같 이 heptanal과 eugenol의 GCS 시스템에서 GSH 변화를 통해 피부의 자극성 및 감작성의 탐색 가능성이 확인되었다. 그러나 $\mathrm{GCS}$ 시스템을 통해 더 많은 피부 자극성 및 감작성 양성물질의 활성화에 대한 경향성을 확인할 필요성이 있다.

\section{Acknowledgements}

이 연구는 환경부에서 지원하는 화학물질 유·위해성 정보관리 전문인력 양성사업의 지원으로 이루어졌으며 이에 대해 감사의 말씀을 드립니다.

\section{References}

Agner T, Serup J. Sodium lauryl sulphate for irritant patch testing: a dose-response study using bioengineering methods for determination of skin irritation. Journal of Investigative Dermatology, 95: 543-547, 1990.

Ahmad N, Mukhtar H. Cytochrome p450: a target for drug development for skin diseases. Journal of Investigative Dermatology, 123: 417-425, 2004.

Anadón A, Martínez MA, Castellano V, Martínez-Larrañaga MR. The role of in vitro methods as alternatives to animals in toxicity testing. Expert Opinion on Drug Metabolism \& Toxicology, 10: 67-79, 2014.

Bandyopadhyay U, Das D, Banerjee RK. Reactive oxygen species: oxidative damage and pathogenesis. Current Science, 77: 658-666, 1999.

Barel AO, Paye M, Maibach HI. Handbook of cosmetic science and technology. CRC press, Boca Raton, pp353-365, 2014.

Bergström MA, Ott H, Carlsson A, Neis M, Zwadlo-Klarwasser G, Jonsson CA, Merk HF, Karlberg AT, Baron JM. A skinlike cytochrome P450 cocktail activates prohaptens to contact allergenic metabolites. Journal of Investigative Dermatology, 127: 1145-1153, 2007.

Betharia S, Farris FF, Corcoran GB, Ray SD. Mechanisms of toxicity. In: Encyclopedia of toxicology 3rd edition. Wexler P (ed). Elsevier Academic Press, Oxford, pp165-175, 2014.

Clayton GD, Clayton FE. Patty's industrial hygiene and toxicology. Wiley Interscience, New York, p2635, 1982.

Dupuis G, Benezra C, Schlewer G, Stampf JL. Allergic contact dermatitis to alpha-methylene-gamma-butyrolactones. preparation of alantolactone-protein conjugates and induction of contact sensitivity in the guinea pig by analantolactone-skin protein conjugate. Molecular Immunology, 17: 1045-1051, 1980.

Golla S, Madihally S, Robinson RL Jr, Gasem KA. Quantitative structure-property relationships modeling of skin irritation. Toxicology in Vitro, 23: 176-184, 2009.

Götz C, Pfeiffer R, Tigges J, Blatz V, Jäckh C, Freytag EM, Fabian E, Landsiedel R, Merk HF, Krutmann J, et al. Xenobiotic metabolism capacities of human skin in comparison with a 3D epidermis model and keratinocyte-based cell culture as in vitro alternatives for chemical testing: activating enzymes (Phase I). Experimental Dermatology, 21: 358-363, 2012.

Hong YH, Jung EY, Suh HJ. Oral and topical safety evaluation of porcine placenta extract for the development of 
the functional ingredient using animal models. Asian Journal of Beauty and Cosmetology, 12: 733-743, 2014. Jones DP. Redox potential of GSH/GSSG couple: assay and biological significance. Methods in Enzymology, 348: 93-112, 2002.

Jugert FK, Agarwal R, Kuhn A, Bickers DR, Merk HF, Mukhtar $\mathrm{H}$. Multiple cytochrome P450 isozymes in murine skin: induction of P450 1A, 2B, 2E, and $3 \mathrm{~A}$ by dexamethasone. Journal of Investigative Dermatology, 102: 970-975, 1994.

Kaplowitz N. Idiosyncratic drug hepatotoxicity. Nature Reviews Drug Discovery, 4: 489-499, 2005.

Khan WA, Park SS, Gelboin HV, Bickers DR, Mukthar H. Monoclonal antibodies directed characterization of epidermal and hepatic cytochrome P-450 isozymes induced by skin application of therapeutic crude coal tar. Journal of Investigative Dermatology, 93: 40-45, 1989.

$\mathrm{Kim} \mathrm{BH}$. The introduction of alternative method of reconstructed human skin equivalents for the assessment of skin irritation. Asian Journal of Beauty and Cosmetology, 9: 1-9, 2011.

Lee AY, Lee YR, Kim JY, Jung JH, Park YK, Kim YJ, Lee SN, An $S$, Bae S. In vitro assessment of irritation potential of an anti-melanogenic agent, PF3758309, in a reconstructed human epidermis model. Asian Journal of Beauty and Cosmetology, 16: 417-425, 2018.

Lee JK, Lee EH, Kim MJ, Kim JH, Min YS, Kim HG, Kim HR. Current status of alternatives to animal experiments in advanced foreign countries. Journal of Alternatives to Animal Experiments, 10: 29-44, 2016.

Lee KE, Nam JJ, Kim SM, Kim HK, Moon SJ, Youm JK. Antiinflammatory effects of the mixture of Sorbus commixta, Urtica dioica, Phyllostachysnigra, and Rhus semialata Gall extracts on LPS-induced inflammation in HaCaT cells. Journal of the Society of Cosmetic Scientists of Korea, 40: 45-54, 2014.

LoPachin RM, DeCaprio AP. Protein adduct formation as a molecular mechanism in neurotoxicity. Toxicological Science, 86: 214-225, 2005.

Lu SC. Regulation of glutathione synthesis. Molecular Aspects of Medicine, 30: 42-59, 2009.

Madden JC, Webb S, Enoch SJ, Colley HE, Murdoch C, Shipley R, Sharma P, Yang C, Cronin MTD. In silico prediction of skin metabolism and its implication in toxicity assessment. Computational Toxicology, 3: 4457, 2017.

Mercer AE, Regan SL, Hirst CM, Graham EE, Antoine DJ, Benson CA, Williams DP, Foster J, Kenna JG, Park BK. Functional and toxicological consequences of metabolic bioactivation of methapyrilene via thiophene S-oxidation: induction of cell defence, apoptosis and hepatic necrosis. Toxicology and Applied Pharmacology, 239: 297-305, 2009.

Merk HF, Jugert FK, Frankenberg S. Biotransformation in the skin. In Dermatotoxicology. Marzulli FN, Maibach HI (eds), Taylor and Francis, London, pp61-73, 1996.

Nizioł-Łukaszewska Z, Osika P, Wasilewski T, Bujak T. Hydrophilic dogwood extracts as materials for reducing the skin irritation potential of body wash cosmetics. Molecules, 22: E320, 2017.

OECD. Test No. 471: bacterial reverse mutation test, OECD guidelines for the testing of chemicals, section 4. OECD Publishing, Paris, 1997.

OECD. Test No. 439: in vitro skin irritation: reconstructed human epidermis test method, OECD guidelines for the testing of chemicals, section 4. OECD Publishing, Paris, 2013.

OECD. Test No. 473: in vitro mammalian chromosomal aberration test, OECD guidelines for the testing of Chemicals, section 4. OECD Publishing, Paris, 2016.

OECD. Test No.429: skin sensitization: local lymph node assay, OECD guidelines for the testing of chemicals, section 4. OECD Publishing, Paris, 2010a.

OECD. Test No. 442A: skin sensitization: local lymph node assay: DA, OECD guidelines for the testing of chemicals, section 4. OECD Publishing, Paris, 2010b.

OECD. Test No. 442B: skin sensitization: local lymph node assay: BrdU-ELISA or -FCM, OECD guidelines for the testing of Chemicals, section 4. OECD Publishing, Paris, 2018.

Park YC, Lee S, Cho MH. The simplest flowchart stating the mechanisms for organic xenobiotics-induced toxicity: can it possibly be accepted as a "central dogma" for toxic mechanisms? Toxicology Research, 30: 179-184, 2014.

Park YC. The molecular \& biochemical principles for toxicology. Korean studies information, Paju, p23, 2010. 
Patlewicz G, Basketter DA, Smith CK, Hotchkiss SA, Roberts DW. Skin-sensitization structure-activity relationships for aldehydes. Contact Dermatitis, 44: 331-336, 2001.

Reisinger K, Hoffmann S, Alépée N, Ashikaga T, Barroso J, Elcombe C, Gellatly N, Galbiati V, Gibbs S, Groux H, et al. Systematic evaluation of non-animal test methods for skin sensitisation safety assessment. Toxicology in Vitro, 29: 259-270, 2015.

Rhein LD, Schlossman M, O'Lenick A, Somasundaran P. Surfactants in personal care products and decorative cosmetics. CRC Press, USA, p345, 2006.

Son JS, Seo YR. Review of alternative methods for the safety assessment of cosmetic ingredients: in terms of skin irritation, sensitization and phototoxicity. Journal of Cancer Prevention, 17: 270-279, 2012.

Thompson D, Constantin-Teodosiu D, Egestad B, Mickos H, Moldéus P. Formation of glutathione conjugates during oxidation of eugenol by microsomal fractions of rat liver and lung. Biochemical Pharmacology, 39: 1587-1595, 1990.
Welss T, Basketter DA, Schröder KR. In vitro skin irritation: facts and future. state of the art review of mechanisms and models. Toxicology in Vitro, 18: 231-243, 2004.

Weston JK, Uetrecht J. Activation of inflammasomes by agents causing idiosyncratic skin reactions: a possible biomarker. Chemical Research in Toxicology, 27: 949951, 2014.

Winterbourn CC, Hampton MB. Thiol chemistry and specificity in redox signaling. Free Radical Biology and Medicine, 45: 549-561, 2008.

Yang SM, Cho KS, Bang MJ, Kim KB, Lee BM, Shin CY. Investigation method for toxicity profile of cosmetics ingredients and trends in safety evaluation. Regulatory Research on Food, Drug \& Cosmetic, 10: 131-139, 2015.

Yin $\mathrm{H}, \mathrm{Xu}$ L, Porter NA. Free radical lipid peroxidation: mechanisms and analysis. Chemical reviews, 111: 5944-5972, 2011. 


\section{국문초록}

\section{글루타치온을 이용한 피부접촉물질에 초기 독성 탐색 기술}

허혜선 ${ }^{1}$ 안민지 ${ }^{1}$, 윤미숙 ${ }^{2}$, 박영철 ${ }^{1 *}$

${ }^{1}$ 대구가톨릭대학교 화학물질독성평가학과 \& GLP센터, 경상북도 경산시, 한국

${ }^{2}$ 계명문화대학교 뷰티코디네이션학부, 대구, 한국

목적: 화학물질의 대사계인 S9 fraction를 이용하는 유전독성시험 in vitro 시스템에 단백질-유사 기능으로 기대되는 glutathione (GSH)를 추가하여 화학물질의 피부의 자극성 및 감작성을 탐색할 수 있는 동물대체시험법으로 glutathione-containing screen system (GCS system)을 개발하는 것이 목적이다. 방법: 자극성 및 감작성의 물질은 유해활성산소 및 유기 라디칼을 생성하거나 단 백질과 결합하여 GSH 감소 및 GSH 산화형인 glutathione disulfide (GSSG)의 증가를 유도한다. 이러한 점을 고려하여 자극성 및 감작성을 탐색하기 위해 total GSH와 GSSG/GSH 비 등의 GSH 변화를 측정하였다. 결과: 피부자극성 양성물질인 heptanal에 의해 total GSH가 감소되어 자연분해를 통해 활성화되며 피부감작성 양성물질인 eugenol은 total GSH 감소와 더불어 GSSG/GSH ratio 증가가 유도되어 효소에 의한 생화학적 전환을 통해 활성화되는 indirect-acting toxicant로 추정되었다. 결론: 이러한 결과를 고 려할 때 피부자극성물질은 S9 fraction이 없는 direct system, 피부감작성물질은 S9 fraction을 포함하고 있는 indirect system에서 $\mathrm{GSH}$ 에 대한 영향이 클 것으로 추정되었다. 그러나 GCS system의 direct system와 indirect system에서 더 많은 양성물질을 이용한 연구를 통해 시스템에서의 자극성 및 감작성의 잠재적 경향성을 파악하여 개발의 필요성이 있다.

핵심어: Glutathione, 동물대체시헙법, 피부접촉물질, 감작성, 자극성

이 연구는 환경부에서 지원하는 화학물질 유-위해성 정보관리 전문인력 양성사업의 지원으로 이루어졌으며, 이에 대해 감사의 말씀 을 드립니다.

\section{참고문헌}

김배환. 인공피부를 이용한 피부자극 대체시험법 소개. 아시안뷰티화장품학술지, 9: 1-9, 2011.

박영철. 독성학의 분자: 생화학적 원리. 한국학술정보, 파주, $\mathrm{p} 23,2010$.

양성민, 조규석, 방민지, 김규봉, 이병무, 신찬영. 화장품 안전성 자료조사법 및 국내외 화장품 성분 안전성 평가 동향. $F D C$ 법제 연구, 10: 131-139, 2015.

이아영, 이유림, 김지예, 정진혁, 박영금, 김유정, 이성내, 안성관, 배승희. 인체피부모델을 이용한 미백 효능물질 PF3758309의 in vitro 피부 자극성 평가. 아시안뷰티화장품학술지, 16: 417-425, 2018.

이진구, 이은호, 김명주, 김주환, 민영실, 김형건, 김학림. 선진 외국의 동물 실험 대안의 현황. 한국동물실험대체법학회 지, 10: 29-44, 2016.

홍양희, 정은영, 서형주. 기능성 소재 개발을 위한 돼지태반추출물의 경구 및 피부 동물모델 안정성 평가. 아시안뷰티화장 품학술지, 12: 733-743, 2014. 


\section{中文摘要}

\section{利用谷胱甘肽对皮肤接触材料的初始毒性篮选技术}

許惠善 ${ }^{1}$, 安盿持 ${ }^{1}$ 尹美淑 ${ }^{2}$, 朴英澈 ${ }^{*}$

${ }^{1}$ 大邱天主教大学 化学物质毒性评价学科\&GLP中心，庆尚北道庆山市，韩国

${ }^{2}$ 启明文化大学美容协调学科, 大邱，韩国

目的: 我们开发了一种含谷胱甘肽的篮选 (GCS) 系统, 能够在物质篮选阶段确认毒性, 旨在减少化妆品原料开 发阶段的时间和成本。方法: 基于遗传毒性测试, 开发了包含直接和间接系统的GCS系统, 以减少在筛选候选化 妆品物质期间鉴定毒性的时间和成本。通过鉴定仅与有毒物质结合的总谷胱甘肽（GSH）和在谷胱甘肽二硫化 物（GSSG/GSH比例中的含量的变化来确认毒性潜力。结果：庚醛是皮肤刺激试验中的阳性对照物质，显示总 GSH降低，并被确定为直接作用毒物。Eugenol是皮肤致敏试验中的阳性对照物质，显示总GSH降低和GSSG/ GSH比值改变，并被鉴定为间接作用毒物。结论：GCS系统可以识别皮肤刺激和致敏的毒性特征。然而，根据 GCS系统, 直接和间接系统, 需要更多的阳性化学物质来诱导皮肤刺激或致敏以挑战化学品的毒性分类, 例如 刺激或致敏。

关键词: 谷胱甘肽，GCS系统，遗传毒性试验，庚醛，丁香酚 
